\title{
Cluster analysis of decarbonisation of the regional economy in the context of the potential of united territorial communities and the alter global vector of development
}

\author{
Olena Trofymenko ${ }^{1,3, *}$, Serhii Voitko ${ }^{1}$, Anatoliy Mokiy ${ }^{2}$, Olha Ilyash $^{1,3}$ and Nataliia \\ Kuzminska $^{1}$ \\ ${ }^{1}$ National Technical University of Ukraine "Igor Sikorsky Kyiv Polytechnic Institute", Faculty of \\ Management and Marketing, 37 Victory avenue, building 1, Kyiv, Ukraine, 03056 \\ 2 Dolishniy Institute of Regional Research of National academy of Sciences of Ukraine, Regional \\ Economic Policy Department, Lviv, Ukraine, Kozel'nyts'ka St., 4, 79026 \\ ${ }^{3}$ International University of Finance, 37 Victory avenue, building 1, Kyiv, Ukraine, 03056
}

\begin{abstract}
Research background: The article examines the peculiarities of the economy decarbonisation in Ukraine's regions using cluster analysis, which helped to determine the composition of clusters of regions with a similar level of the economy decarbonisation and common features. The study takes into account specific indicators. Close attention is paid to the study of the dynamics of carbon dioxide emissions into the atmosphere from stationary sources per unit of gross regional product in certain clusters and to the identification of factors and measures to reduce them. The development of energy innovations is identified as a key area for decarbonisation of regional economies. The role of decentralization reform is analysed and regarded as a factor in the growth of decarbonisation and development of energy projects in united territorial communities, which, in general, increases the level of effectiveness of the regional policy on innovative development of the energy sector.

Purpose of the article: to identify key factors in the growth of decarbonisation of the economy of the regions.

Methods: general scientific methods were used, the main of which are: cluster analysis - to identify clusters of regions with a similar level of decarbonisation of the economy, system analysis - to apply a comprehensive approach to the study of factors influencing the growth of decarbonisation of the economy and determining an effective balanced regional policy towards innovative development of the energy sector.

Findings \& Value added: The directions of balancing the regional policy towards ensuring innovative development of the energy sector of the national economy in the conditions of Industry 4.0 are determined.
\end{abstract}

\footnotetext{
*Corresponding author: o.o.trofymenko@gmail.com
} 
Keywords: decarbonisation of the economy; energy innovation; clusters of regions; decentralization reform

JEL Classification: $O 18 ; P 48 ; Q 28$

\section{Introduction}

An important issue that is currently at the cutting edge of research is the formation of appropriate conditions for the transformation of the energy sector. New historical conditions and the European Green Course require a rethink of the role and place of energy innovation, due to the new challenges and opportunities of Industry 4.0, as well as the need to ensure sustainable development of Ukraine's regions in the direction of decarbonisation of united territorial communities (UTC). The development of mechanisms for innovative development of the energy sector of the national economy in the conditions of dynamic development of Industry 4.0. needs system research into the state policy on innovative development of the energy sector and the development of an effective mechanism for decarbonisation of regional economies. The necessity of defining strategic priorities and an effective state policy on regional development of Ukraine in the direction of decarbonisation of UTC requires the definition of regional clusters where similar mechanisms of state regulation in the energy sector can be applied.

On the one hand, this study is based on the use of cluster analysis, and on the other hand - on the conceptual directions of state support for decarbonisation of the economy in the light of alterglobalism. Cluster analysis is widely applied in modern economic research (Corbi et al., 2019; Gruzauskas et al., 2021; Majerova \& Nevima, 2017). The global needs of mankind in the direction of achieving climate neutrality lead to the growth in the number of scientific work in the field of research on decarbonisation of the economy and energy (Arabzadeh et al., 2020; Bistline \& Blanford, 2021; Hartmann et al., 2021; Ilyash et al., 2021; Iverson \& Karp, 2021; Voitko et al., 2021; Patnaik, 2019; Rui Li et al., 2020; Shapiro, 2021). Given the relevance of this issue, this study focuses on identifying clusters of regions with similar signs of decarbonisation of the economy. For this purpose, the use of a set of indicators of the economy decarbonisation is proposed; it helps to ensure an effective state policy in the defined regions, taking into consideration the potential of united territorial communities.

\section{Methods}

Hierarchical cluster analysis is used for the study as in this analysis each observation first forms a separate cluster. In the first stage of the analysis, two adjacent clusters are merged into one. This process continues until only two clusters remain. The distance between clusters is the average of all distances between all possible pairs of points from both clusters.

The cluster analysis of regions in terms of decarbonisation of the economy was conducted in the following stages:

1) the formulation of the problem. To determine the directions of regional and comprehensive state policies on decarbonisation, it is important to take into account common and distinctive features of regions to devise an effective state regional policy. Therefore, the regions of Ukraine were systematised based on similar features, which helps to assess the level of economic development, energy and anthropogenic impact on the region in terms of $\mathrm{CO} 2$ emissions;

2) the choice of a method of measuring the distance (determining the degree of similarity of objects). In the study, the square of the Euclidean distance was chosen as a measure of similarity: 


$$
d(x, y)=\sum_{i=1}^{n}\left(x_{i}-y_{i}\right)^{2}
$$

3) the choice of a clustering method. A clustering method is a method of calculating the distances between clusters. For the analysis, Ward's method was chosen. The essence of this method lies in the fact that first the calculation of the average values of individual variables is made in both clusters for all observations. Then, it is necessary to calculate the squares of the Euclidean distances from the individual observations of each cluster to the calculated cluster average. All distances are totalled up. Next, the clusters that give the smallest increase to the total number of distances are combined into one new cluster.

4) deciding on the number of clusters.

5) the interpretation and profiling of clusters;

6) the assessment of the reliability of clustering.

Thus, to conduct a cluster analysis in order to determine clusters of the regions with a similar level of decarbonisation of the economy, the following indicators were identified:

- D1 - emissions of carbon dioxide into the atmosphere from stationary sources of emissions by regions (emissions of carbon dioxide into the atmosphere from stationary sources of emissions, thousand tons);

- D2 - the volume of sold industrial products by regions (million UAH, excluding VAT and excise duty);

- D3 - electricity production by regions, (million $\mathrm{kWh}$ );

- D4 - gross regional product per capita, at actual prices, UAH

The cluster analysis was conducted for 24 regions of Ukraine and the city of Kyiv. The results of the cluster analysis employing Ward's hierarchical method were obtained with the use of the software package IBM SPSS Statistics 20.0.

\section{Results}

Each region of Ukraine has its own characteristics in accordance with the resource potential, geographical conditions and historical features of its development. At the same time, in order to form recommendations at the level of the national economy concerning the introduction of energy innovation for the purpose of decarbonisation, it is necessary to identify regional clusters where similar mechanisms of state regulation in the energy sector can be applied.

According to the calculations obtained by the method of hierarchical cluster analysis, it was possible to single out 6 clusters of regions (Fig. 1), as well as isolate regions that are not included in these clusters and are located separately. The 6 clusters comprise the following associations of regions in 2018: cluster №1, which includes Zhytomyr, Sumy, Odesa, Rivne, Khmelnytskyi, Volyn, Kherson, Kirovohrad, Chernihiv, Zakarpattia, Ternopil, Chernivtsi, Luhansk regions; cluster №2 includes Vinnytsia, Cherkasy, Ivano-Frankivsk, Mykolaiv, Lviv, Kyiv regions; cluster №3 includes Poltava, Kharkiv, Zaporizhzhia regions; Donetsk region belongs to cluster №4; cluster №5 includes the city of Kyiv and cluster №6 includes Dnipropetrovsk region. Compared to 2018, in 2019 the clusters of regions were almost identical, except that the Odesa region moved from cluster №1 to cluster №2. Let us consider the clusters in more detail.

It is obvious that the regions that are part of cluster 1 stand out; this is the largest cluster. In this cluster, there are regions bordering on other countries and on the temporarily occupied territory of Crimea; separately, there is the 'vertical' in the west of Ukraine from the Rivne to Chernivtsi region. This is the largest territorial 'clump' for this cluster. In addition, the peculiarity of this region is relatively low population density in the regions and the great focus on agricultural development and small focus on industrial development. 
Border regions to some extent depend on the foreign economic activity of entrepreneurs from these areas and the business they have with border countries. The Kirovohrad region differs slightly as it does not have a direct border with other regions of this cluster but is characterised by the presence of similar features to those of other regions according to the given method and selected parameters.

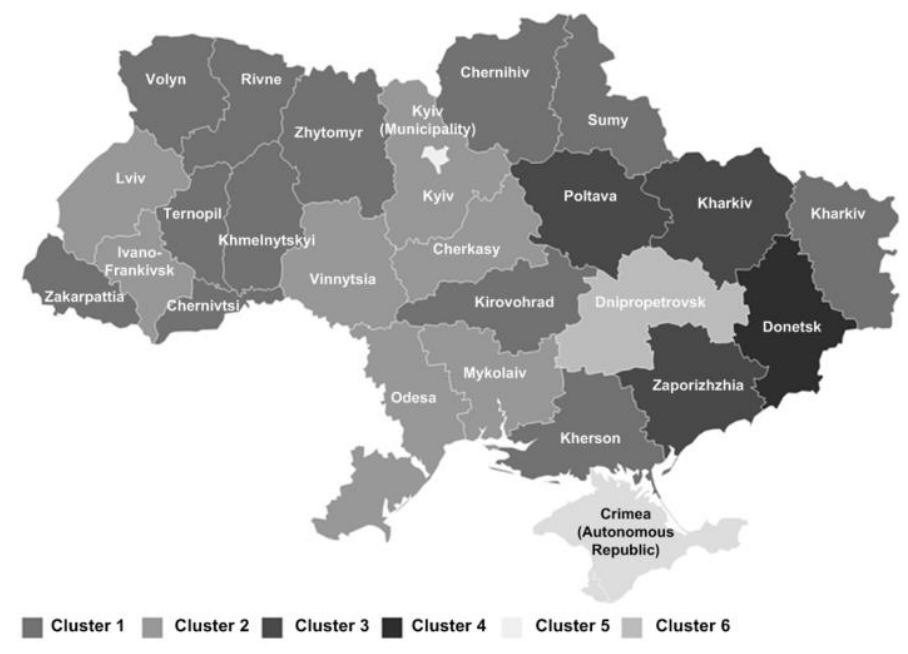

Figure 1. Visualization of the clusters of Ukraine's regions by the level of decarbonisation

Source: designed by the authors on the basis of data (State Statistics service of Ukraine, 2021)

Let us analyse the identified clusters in terms of carbon dioxide emissions into the atmosphere from stationary sources of emissions per unit of gross regional product, thousand tons per billion UAH. This figure characterises how many thousands of tons of carbon dioxide emissions is per each billion of gross regional product generated. At the same time, the dynamics of this indicator is more illustrative - its decrease is a positive phenomenon for achieving carbon neutrality in Ukraine.

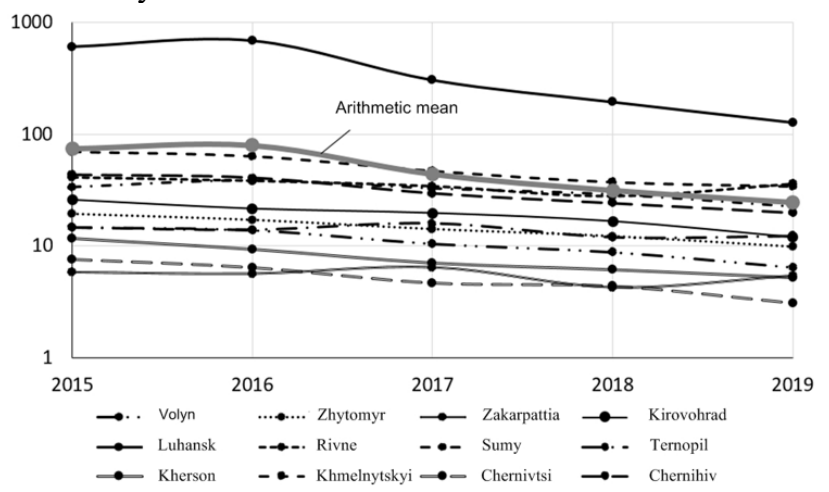

Figure 2. Dynamics of the indicator of carbon dioxide emissions into the atmosphere from stationary sources of emissions per unit of gross regional product (thousand tons per billion $\mathrm{UAH}$ ) in the regions of Cluster 1 and the arithmetic mean

Source: Developed by the author 
For instance, in Cluster 1, the largest value of the indicator is observed in the Luhansk region. This is due to a large number of operating enterprises in such highly polluting industries as mining (coal mining), mechanical engineering, metallurgy, chemical industry, oil refining and other industries. At the same time, one can notice the positive dynamics in the Luhansk region - a decrease from 607.74 thousand tons per billion UAH in 2015 to 127.86 thousand tons per billion UAH in 2019. Moreover, in 2016, there was a rise in the indicator relative to 2015 and afterwards there was a fall. This can be explained by the fact that in 2016 new increased environmental tax rates were introduced. There was a gradual decline in such regions as Khmelnytskyi, Sumy, Zhytomyr, Volyn, Kherson, Chernivtsi regions. At the same time, in Zakarpattia, Ternopil and Rivne regions there was a similar wave-like dependence of the indicator with its further growth in 2019. Therefore, it can be argued that these three regions stand out by similar dynamics of carbon dioxide emissions into the atmosphere from stationary sources of emissions per unit of gross regional product, which fluctuates cyclically, and it cannot be considered a positive phenomenon. These three regions have common borders and, accordingly, similar economic conditions. The Rivne region is the most industrially developed region among them. To illustrate, the leading industries in the Rivne region are the production and supply of electricity and gas; chemical industry; the production of building materials and glassware; food industry; wood products manufacture; mechanical engineering. The industry of the region specialises mainly in the production of electricity, fertilizers, glassware, particle board, plywood, cement, building materials, power switches, nonwovens, confectionery.

It is important to establish effective mechanisms at the state level to reduce emissions from industry (Kurbatova et al., 2021). To do this, it is advisable to adapt global initiatives in the direction of climate neutrality. For example, the dynamics of growth of carbon dioxide emissions into the atmosphere from stationary sources of emissions per unit of gross regional product is observed in these three regions in the cluster, in spite of the fact that they have a relatively small volume of industry and gross regional product.

The second cluster includes industrialised regions with the corresponding energy needs. It should be noted that there is the "vertical» from the Kyiv to Odesa region and a certain group of Lviv and Ivano-Frankivsk regions, which are quite developed energetically and industrially. The eastern part of Ukraine is characterised by developed industry. However, the highest rate of carbon dioxide emissions into the atmosphere from stationary sources of emissions per unit of gross regional product is observed in the Ivano-Frankivsk region (Fig. 3 ), which is more than 3 times higher than in the Lviv region (2019). It is worth mentioning that the gross regional product in the Lviv region is 1.3 times higher than that in the IvanoFrankivsk region, and the volume of industrial production is almost twice higher. Although the Lviv region has relatively low concentration of heavy industrial facilities, which are the main air pollutants, the region's diversified economy is service-oriented. In the IvanoFrankivsk region, there are highly polluting industries, in particular, electricity generation, chemical and petrochemical production, woodworking, food industry, production of building materials, mechanical engineering, extraction of energy materials, etc. There is a powerful Burshtyn TPP, which is estimated to be the dirtiest in Europe; it ranks first in terms of sulphur dioxide emissions and second in terms of fly ash. This region can be described as industrial and agricultural one with favourable natural conditions for the development of renewable energy. In accordance with the development of product specialization in the region, the needs for energy supply are growing, and supply comes mainly from traditional sources. Therefore, it is advisable to stimulate energy innovation. Given the above, renewable energy should be developed in this region in order to diversify the energy supply of industry and reduce the load on the traditional thermal power plant. 
For example, in the Lviv region, there are 6 solar power plants with a capacity of almost $30 \mathrm{MW}, 3$ wind power plants with a total capacity of over $30 \mathrm{MW}$. It is planned to introduce 5 new solar power plants and 2 wind power plants by the end of 2021.

Figure 3 shows that in the Vinnytsia region, the value of carbon dioxide emissions into the atmosphere from stationary sources of emissions per unit of gross regional product was above the average. From 2016 to 2017, there was an increase; from 2017, there was a decrease, which is a positive trend. Enterprises that supply electricity, gas, steam, and conditioned air are engaged in the most polluting type of economic activity in the Vinnytsia region, although in general, this region is characterised by an agricultural type of economy. In this cluster, it is advisable to pay attention to the Vinnytsia region in the context of introducing energy innovation to increase the level of decarbonisation of the region's economy.

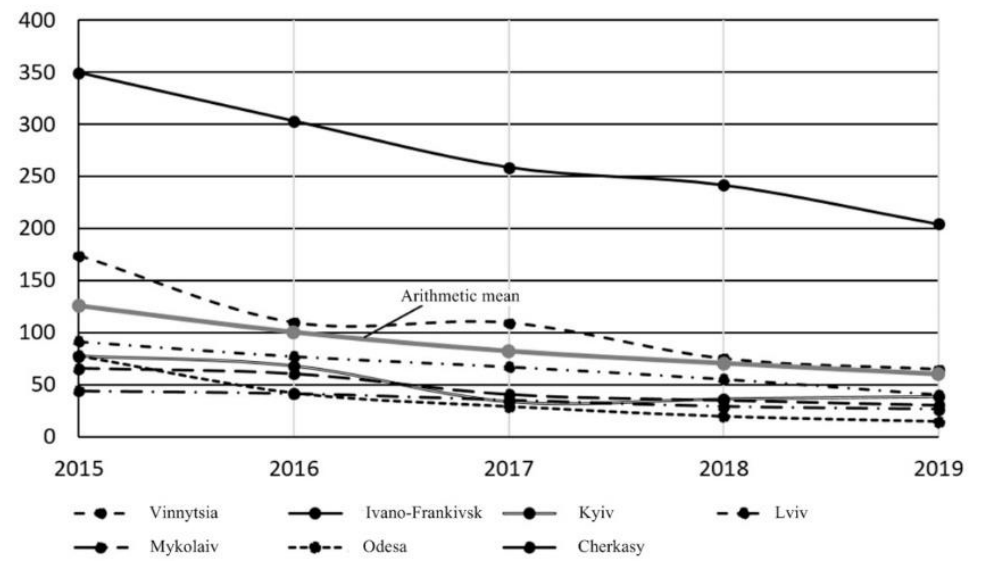

Figure 3. Dynamics of carbon dioxide emissions into the atmosphere from stationary sources of emissions per unit of gross regional product (thousand tons per billion UAH) in the regions of Cluster 2 and the arithmetic mean

Source: Developed by the authors

Poltava, Kharkiv and Zaporizhzhia regions belong to cluster 3 . The peculiarity of the cluster is that these regions consume a significant amount of energy and produce it; also, they have the potential for the development of renewable energy. For instance, the highest level of carbon dioxide emissions into the atmosphere from stationary sources of emissions per unit of gross regional product in this cluster is observed in the Zaporizhzhia region (Fig. 4). The Zaporizhzhia region is characterised by an industrial type of economy with such predominant industries as ferrous metallurgy, electric power industry, mechanical engineering, metalworking production and non-ferrous metallurgy. It is the Zaporizhzhia region that produces the largest amount of electricity among all regions. In 2019, the production amounted to 47456 million $\mathrm{kWh}$. $-31.4 \%$ of all electricity in Ukraine. In addition, it has a large volume of sold industrial products - 195079.2 million UAH and 187344.4 million UAH, in 2019 and 2020 respectively. It should be noted that the region is already implementing projects in the field of renewable energy. There is one of the largest wind power plants in Ukraine - Prymorska wind farm, with a capacity of $100 \mathrm{MW}$, as well as Orlivska wind farm and solar power plants (Energy and Energy Saving, 2019). Compared to 2018 , the volume of produced renewable electricity rose by $71.6 \%$. The growth of electricity generation from renewable sources will continue to have a positive effect on cutting emissions. For this purpose, it is necessary to gradually replace the activity of traditional highly polluting power plants such as «Zaporizhzhia TPP», PJSC «DTEK Dniproenergo», Dnieper HPP, PJSC “Ukrhydroenergo" with renewable energy generation. 
The other two regions of this cluster also have high indicators of GRP and industrial production. However, despite a relatively high volume of industrial production of 175687.7 million UAH and GRP of 92864 million UAH, the Kharkiv region has the lowest rate of carbon dioxide emissions into the atmosphere from stationary sources of emissions per unit of gross regional product. The main activities aimed at improving the air quality in the Kharkiv region are the reduction of emissions of pollutants into the atmosphere from stationary and mobile sources of emissions through the implementation of measures to protect the air.

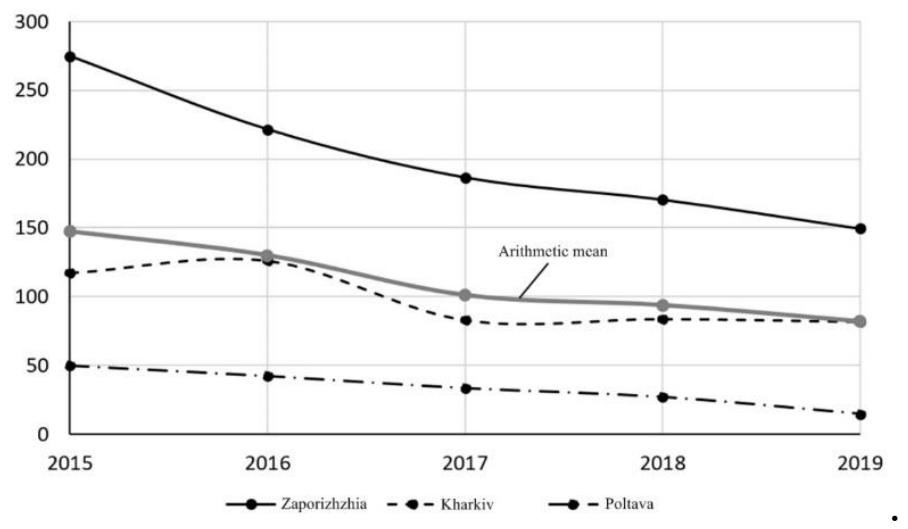

Figure 4. Dynamics of carbon dioxide emissions into the atmosphere from stationary sources of emissions per unit of gross regional product (thousand tons per billion UAH) in the regions of Cluster 3 and the arithmetic mean

Source: Developed by the author

To illustrate, in the Kharkiv region, the main air pollutants are powerful industrial enterprises of the fuel and energy complex such as Zmiivska TPP, PJSC «Centerenergo», the branch «Teploelectrocentral» of LLC «SP oil and gas company», PJSC «Kharkiv CHP-5» (Report, 2019), where measures are taken to reduce the negative impact. For example, there are current repairs to gas purification plants at power units, various organizational and technical measures, measures to determine the set of potential sources and mechanisms of financial support for reconstruction, modernization, technical re-equipment and decommissioning of large combustion plants included in the National Emission Reduction Plan from large combustion plants, approved by the Cabinet of Ministers of Ukraine dated June 13, 2018 № 428-r.

The fourth cluster includes only one region - Donetsk. To a large extent, this position is conditioned by military actions, but this industrialized region is quite close to the developed neighbouring regions. However, the military aggression of the Russian Federation destroyed considerable potential of Donetsk and Luhansk regions. Therefore, the method of dividing objects into clusters has singled out this region in this way. Despite the fact that some part of the region is temporarily occupied, the Donetsk region ranks second in the total volume of sold Ukrainian products after the Dnipropetrovsk region - the volume of sold industrial products is 179.5 billion UAH, which is $12.7 \%$ (Brief results, 2018). The region is dominated by the industrial type of economy with the following types of industry: mining industry and quarry development; metallurgy, manufacture of coke, refined petroleum products; production of chemicals and chemical products; mechanical engineering; production, supply and distribution of electricity, gas, steam and conditioned air, etc.

By the indicator of carbon dioxide emissions into the atmosphere from stationary sources of emissions per unit of gross regional product, there is a positive trend. According to the 
data from Donetsk region, energy saving, and energy efficient measures are adopted at the enterprises of the region.

In addition, the region uses the potential of non-traditional energy sources such as wind energy, agricultural waste, biomass, blast-furnace and coke-oven gases. The use of nontraditional energy sources allowed the region to save 7.92 thousand toe, including electricity -16.97 million $\mathrm{kWh}$, heat energy -13.96 thousand Gcal in 2019 . The fifth cluster is the city of Kyiv. The isolation is explained by the fact that the city has the largest concentration of population; the administrative centre houses legislative and executive bodies, the banking system and other state bodies. Furthermore, the city has great potential for the development of renewable energy and consumes considerable amounts of energy. The Dnipropetrovsk region deserves attention as it is placed into a separate cluster according to the method adopted for the study. The explanation for this is a fairly developed industry, agriculture and transport corridors. Renewable energy has enormous potential for development. Innovation is properly represented in this region, in particular in the field of Industry 4.0, in the aerospace field, etc.
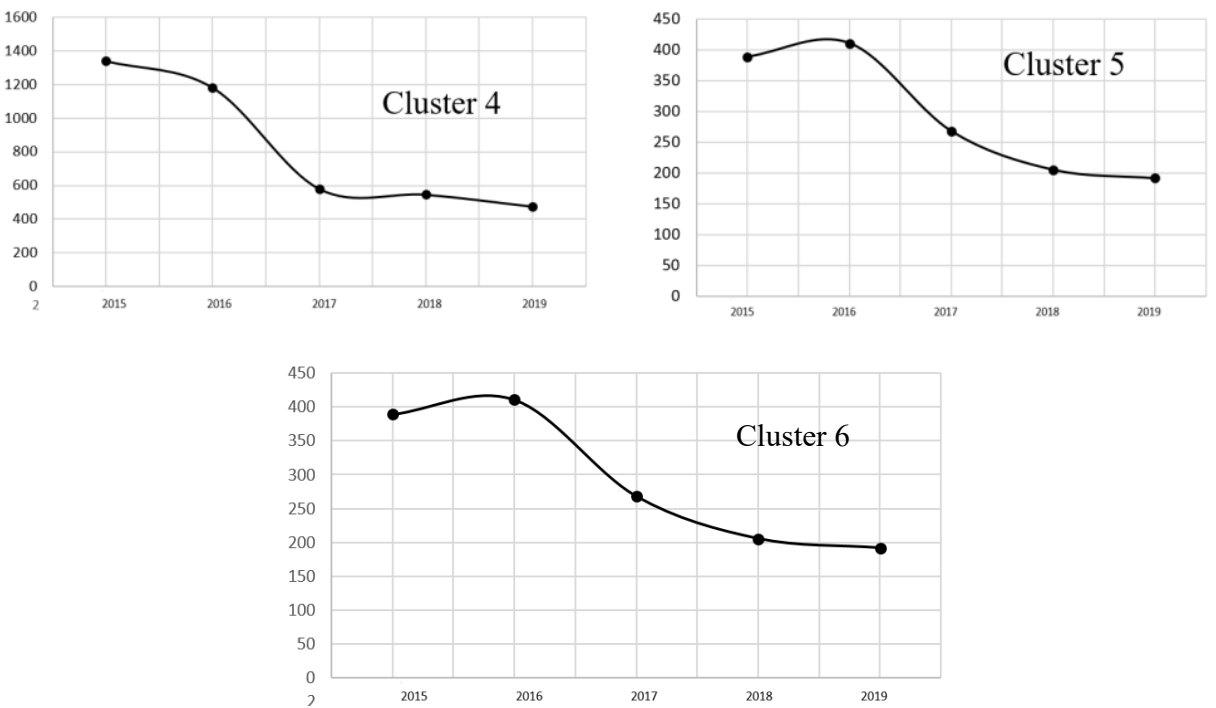

Figure 5. Dynamics of carbon dioxide emissions into the atmosphere from stationary sources of emissions per unit of gross regional product (thousand tons per billion UAH) in Cluster 4 (Donetsk region), Cluster 5 (the city of Kyiv), Cluster 6 (Dnipropetrovsk region)

Source: designed by the authors on the basis of data (State Statistics service of Ukraine, 2021)

The Autonomous Republic of Crimea was not considered in the study due to the temporary occupation of the territory by the Russian Federation, which hinders the process of obtaining data for cluster analysis.

Since decentralization reform is being actively implemented today, making such decisions at the level of united territorial communities is an important direction for ensuring energy supply and introducing innovation in the energy sector. It should be noted that at present, in the conditions of decentralization, communities have the opportunity to independently manage their own budget, and more sources of replenishing it. Consequently, as of 2020, according to the data (State Statistics service of Ukraine, 2021) and the total number of UTCs by cluster regions, we have the following figures: 647 UTCs are formed in cluster 1, 476 UTCs belong to cluster 2, 183 UTCs are in cluster 3, 46 UTCs are in cluster 4, 1 UTC is found in cluster 5, 86 UTCs are in cluster 6 . The decentralization reform is still 
taking place, and the state authorities are transferring much of the powers, resources (including financial) and responsibilities to local self-government bodies in order to ensure quality and safety of life of the population. This policy is based on the provisions of the European Charter of Local Self-Government and the implementation of effective world standards of public relations in this area. At the same time, the low investment activity of the state and local communities in the financial support of the innovation sphere is an especially significant drawback. (Ilyash et. al, 2021). That is why the introduction of energy innovation should be initiated at the level of UTC to ensure decarbonisation in the regions in general.

To understand what resource is involved in energy conservation or efficient use of energy, it is necessary to realise how much energy is actually consumed by the community, where the community can save and what measures will be the most effective. It is also reasonable to take into account social, economic, institutional, technological and environmental aspects of community development (Mokiy et. al. (2020, 2021)

Some innovative projects in the field of energy saving, energy efficiency and renewable energy are as follows: a thermal modernization project (Balta City UTC, Odesa region); the «Street lighting" project, village Sosnytsia - the reconstruction of Sosnytsia UTC (Chernihiv region); the project of industrial production of solar electricity from Global Ecopower SA (Khoroshiv village UTC, Zhytomyr region); the project to build a solar power plant that will operate to supply water to houses (Tomashpil UTC, Vinnytsia region); the project of construction of a solar power plant «Bohorodchanska-1» (Stari Bohorodchany UTC, IvanoFrankivsk region); a hybrid power plant with solar panels (Shakhove UTC, Donetsk region); the project of installation of solar batteries (Mala Pereshchepyna UTC, Poltava region); projects of construction of solar power plants (Bozhedarivka UTC, Dnipropetrovsk region) energy saving projects (Melitopol city UTC, Zaporizhzhia region), etc.

Providing state support for energy saving projects at the level of united territorial communities will present an opportunity to ensure decarbonisation of the regions on the basis of alterglobalism.

\section{Conclusions}

It is important to devise and implement an economic approach to developing UTC and improving the quality and safety of life of the population. This also includes the development of energy innovation in communities, which will be based on the application of elements of economic zoning i.e., the identification of economic territories, which differ in the specialization and structure of production, natural and human resources, as well as in economic and geographical location, taking into account the indicators of decarbonisation of the economy. The following main stages of the economic approach to developing UTC in the direction of decarbonisation of the economy were formed:

- The analysis of UTC in the context of the development of the defined clusters by the indicators of decarbonisation of the economy. To do this, we suggest using cluster analysis by four indicators. In addition, there is an interesting and effective methodology for determining the typology of Ukraine's regions in the context of developing the State Strategy for Regional Development until 2027, proposed by a group of advisers on the implementation of state regional policy in Ukraine - "ULEAD with Europe" programme together with the Regional Development Directorate of the Ministry of Regional Development [6]. According to the results of our study, we propose adjusting this methodology - adding the indicators of decarbonisation of the economy.

- The identification of those factors in regional development in the energy sector, which are common to UTC. 
- The comparison of UTC indicators with the average values of regional indicators in the energy sector.

Moreover, for the analysis of UTC, it is essential to explore the available potential of natural resources, property, infrastructure, labour resources of UTC and to carry out a socioeconomic assessment of UTC, in particular, the indicators of energy supply of communities.

However, it should be noted that depending on the regional location of UTC, communities use different approaches to the introduction of energy-saving technologies in their territories.

The development of energy innovation should be accompanied by the positive effects of Industry 4.0. in UTC, in particular, by an increase in the level of informatization, which contributes to the willingness to innovate. All this will help to form an economic basis for involving a wide range of civil society entities in the process of creating open data in order to ensure an effective use of the UTC budget and increase the level of transparency of local authorities in UTC with the purpose of improving innovative development in the energy sector.

\section{Acknowledgements}

The results of this study were tested in the Makariv village territorial community and taken into account when devising a development strategy of the Makariv village territorial community (reference №358 from 10.03.2021).

\section{References}

1. Arabzadeh, V., Mikkola, J., Jasiūnas, J., \& Lund, P. D. (2020). Deep decarbonization of urban energy systems through renewable energy and sector-coupling flexibility strategies. Journal of Environmental Management, 260, 110090.

2. Bistline, J. E., \& Blanford, G. J. (2021). Impact of carbon dioxide removal technologies on deep decarbonization of the electric power sector. Nature Communications, 12(1).

3. Brief results. Donetsk Regional State Administration. (2018). Retrieved September 25, 2021, from https://dn.gov.ua/ekonomika/socialnij-ta-ekonomichnij-rozvitokregionu/korotki-pidsumki

4. Corbi, R., Papaioannou, E., \& Surico, P. (2019). Regional transfer multipliers. The Review of Economic Studies, 86(5), 1901-1934.

5. Energy and Energy Saving / Energy and Energy Saving for 2019. Zaporizhia Regional State Administration. (2020, February 3). Retrieved September 25, 2021, from https://www.zoda.gov.ua/news/48810/energetika-ta-energozberezhennya-za-2019$\underline{\text { rik.html }}$

6. Gruzauskas, V., Calneryte, D., Fyleris, T., \& Krisciunas, A. (2021). Application of multivariate time series cluster analysis to regional socioeconomic indicators of municipalities. Real Estate Management and Valuation, 29(3), 39-51.

7. Hartmann, J., Inkpen, A. C., \& Ramaswamy, K. (2021). Different shades of green: Global oil and gas companies and renewable energy. Journal of International Business Studies, 52(5), 879-903.

8. Ilyash O., Lupak R., Vasyltsiv T., Trofymenko O. and Dzhadan I. (2021). Modelling of the Dependencies of Industrial Development on Marketing Efficiency, Innovation and Technological Activity Indicators. Ekonomika, 100(1), 94-116.

9. Iverson, T., \& Karp, L. (2021). Carbon taxes and climate commitment with non-constant time preference. The Review of economic studies, 88(2), 764-799. 
10. Patnaik, S. (2019). A cross-country study of collective political strategy: Greenhouse gas regulations in the European Union. Journal of International Business Studies, 50(7), 1130-1155.

11. Majerova, I., \& Nevima, J. (2017). The measurement of human development using the ward method of cluster analysis. Journal of International Studies, 10(2), 239-257.

12. Mokiy A., Ilyash O., Pynda Y., Pikh M., Tyurin V. (2020). Dynamic Characteristics of the Interconnections Urging the Construction Enterprises Development and Regions Economic Growth. TEM Journal, 9(4),1550-1561.

13. Mokiy, A., Pynda, Y., Ilyash, O., Pikh, M. \& Pynda, R. (2021). Characteristics of interconnections of construction sector and environment: regional study of Ukraine. Scientific Review Engineering and Environmental Sciences, 30 (2), 337-353.

14. Kurbatova, T., Sotnyk, I., Kubatko, O., Baranchenko, Y., Arakpogun, E. O., \& Roubik, H. (2020). State support policy for renewable energy development in emerging economies: the case of Ukraine. International Journal of Global Environmental Issues, 19(1-3), 26-52.

15. Report on the condition of the surrounding appropriate environments in the khapkov region in 2018 (2019, December 3). Retrieved September 25, 2021, from https://kharkivoda.gov.ua/content/documents/1006/100511/Attaches/regionalna_dopov id_2018.pdf

16. Li, R., Jiang, H., Sotnyk, I., Kubatko, O., \& Almashaqbeh YA, I. (2020). The CO2 emissions drivers of post-communist economies in Eastern Europe and Central Asia. Atmosphere, 11(9), 1019.

17. Shapiro, J. S. (2021). The environmental bias of trade policy. The Quarterly Journal of Economics, 136(2), 831-886.

18. State Statistics service of Ukraine. (2021). Retrieved September 25, 2021, from https://ukrstat.org/en.

19. Voitko, S., Trofymenko, O., \& Pavlenco, T. (2021). Decarbonisation of the economy through the introduction of innovative technologies into the energy sector. In $E 3 S \mathrm{Web}$ of Conferences (Vol. 255, p. 01016). EDP Sciences. 